Article

\title{
Intertextuality, Christianity and Death: Major Themes in the Poetry of Stevie Smith
}

\author{
Judith Woolf
}

Department of English and Related Literature, University of York, York YO10 5DD, UK; judith.woolf@york.ac.uk

Received: 8 September 2019; Accepted: 30 October 2019; Published: 1 November 2019

check for

updates

\begin{abstract}
Stevie Smith, one of the most productive of twentieth-century poets, is too often remembered simply as the coiner of the four-word punch line of a single short poem. This paper argues that her claim to be seen as a great writer depends on the major themes which-in addition to "death by water"-she shares with T.S. Eliot: Anglicanism and the modern reworking of classical literature, with a strong, and in her case sometimes autobiographical, emphasis on female protagonists. Where the female figures in Eliot's The Waste Land are seen as parodic and diminished contemporary versions of their classical originals, Smith enters and reimagines her classical sources, testing the strength of the narrative material which binds Phèdre, Antigone, Persephone and Helen of Troy to their fates. In contrast to Eliot's adult conversion to Anglo-Catholicism, Smith became a convert to agnosticism, engaging in a passionate poetic argument with the faith of her childhood, which led her to challenge Eliot himself. She brings both of these themes together in the most personal of her poems, which celebrate, and ultimately invoke, Thanatos, "the only god/Who comes as a servant", and who puts a merciful end to all stories by "scattering... the human pattern altogether".
\end{abstract}

Keywords: Stevie Smith; T.S. Eliot; The Waste Land; Greek gods; female protagonists; Christianity; suicide; death

On a mid-December morning in 1965, I went beachcombing with Stevie Smith. She had read her poems to the University of Sussex Literary Society the night before, and now she wanted seashells to take home to Avondale Road as proof that she had been to the seaside. It was my task to find the shells, few of which had survived the grinding shingle, but presently, Stevie pounced on a different kind of flotsam. Holding it up by one limp ray, she identified it in her inimitable voice: "A poor dead starfish." She held it for just long enough to let me wonder if she was going to pop it into her shiny black bag ("and take it home to brew with" added the friend who had breakfasted with us when I told the story later) before dropping it back onto the pebbled shore.

Seamus Heaney famously wrote that Stevie Smith's "own performance of her verse" prompted him to revise Auden's definition of poetry as "memorable speech" to "memorable voice", the "beautifully flawed plainsong" of a performer who was both Gretel and witch, ${ }^{1}$ while Calvin Bedient perceptively described her as "a fearless and therefore fearful mime". ${ }^{2}$ Stevie Smith in performance was a mime artist in words, her sad, expressive eyes and the impeccably unexpected timing of her deadpan delivery reducing audiences to helpless laughter as she felt her way around the bars of the imagined cages, which, one way or another, imprison us all. At the height of her late-flowering fame as a performance artist, to ask Ogden Nash's question, "Who, or what, is Stevie Smith?"3 in real earnest was to be met with astonishment, as the poet Jonathan Williams discovered:

\footnotetext{
Heaney 1991, p. 211

Bedient 1991, p. 167.

Nash 1964.
} 
I remember once picking up a copy of a faded blue book of poems from the thirties in Bertram Rota's bookshop in Vigo Street, London. I asked Arthur Uphill, who was tending the store: so who's Stevie Smith? "Who's Stevie Smith?" he exclaimed, as though I had failed to recognize Queen Victoria, Dame Edith Sitwell, Gertrude Stein, Mae West, and Bette Davis all walking down Saville Row together. ${ }^{4}$

Yet fifty years after that morning on Brighton beach, Amy Jenkins, writing in The Guardian, gives a very different account of her final decade:

the patriarchy got her in the end. In later years she was overlooked-her poems dismissed as light verse-and she was denied membership of the canon. I can't help thinking she was sidelined for having become a plain and eccentric spinster. ${ }^{5}$

Less than six months later, critical acclaim for Will May's 800 page edition of The Collected Poems $\mathcal{E}$ Drawings of Stevie Smith proved Jenkins wrong in her belief that "nowadays, Smith is only really remembered for her 1957 poem 'Not Waving But Drowning'"; though David Orr's description of her, in his review in The New York Times, as "the English poet so odd that even other poets, most of whom are fairly odd themselves, have never been sure what to do with her" suggests that she may still not have found her place in the canon. However, Orr does go on to say, "she is a great poet whether or not she fits into the stories we like to tell about poets and their greatness." ${ }^{\prime 6}$

Establishing Smith's claim to be read as indubitably a major poet, and arguably a modernist one, means moving beyond the aspect of her work represented by her most famous poem. It is all too often supposed that Smith condensed her own autobiography into the twelve short lines of Not Waving but Drowning, ${ }^{7}$ but although the quiet desperation of little lives is certainly one of her poetic subjects, she never saw herself as among those doomed to the unenviable fate of having "no fate at all". ${ }^{8}$ In Novel on Yellow Paper, her alter ego Pompey Casmilus remembers the "one dreadful moment" in which Lewis Carroll's Alice "thought she was going to be Mabel", and tells us "that is just one thing we don't have to worry about ... There are hazards enough in life and death, but Alice can never be Mabel", 9 while the title character of Smith's final book of poems answers the imagined question, "Are you Mrs Briggs, dear?" with the emphatic words, "No, I am Scorpion."10

Although Not Waving but Drowning offers a warning that "it's a tightrope business, this pulling oneself together, and can give rise to misunderstandings which may prove fatal", Smith treats "the poor fellow who got drowned"11 with the same ironic pity as the "poor dead starfish". The poem owes its perennial place in lists of the nation's favourite poems, not because of its central importance in Smith's work - it is not, as Amy Jenkins believes, "her masterpiece" — but because of the neat way its four-word title sums up its equally neat reversal of the story of the boy who cried wolf, and because, as the caption to one of her drawings puts it, "We all have these thoughts sometimes". ${ }^{12}$ While Smith's ability to skewer her unfortunate human subjects in poems that are sometimes little more than epigrams has often led to her being seen simply as a writer of brilliant light verse with a macabre or tragi-comic twist, I would argue that her true stature as a poet can be judged by her treatment of the three major and related themes through which she looks more deeply into the human predicament: the confrontation between struggling mortals and the implacable Greek gods of tragedy, myth and epic;

\footnotetext{
Williams 1991, p. 38.

Jenkins 1915.

Orr 2016.

Smith 2015, p. 347.

Smith 2015, p. 22

Smith 1969, p. 63.

Smith 2015, p. 593

Smith 1981.

Smith 1990.
} 
her life-long argument with the Christian God of her childhood; and her preoccupation with Thanatos, the servant-god of death.

A key feature of the reception of Smith's work is that although critics describe her as a literary one-off, a poetic voice too unique to belong to any school, at the same time, they compile lists of the many other poets she resembles, usually beginning with William Blake, against whom Smith herself felt "one should be on one's guard ... His are very easy echoes to catch". ${ }^{13}$ One of the most perceptive of these lists appeared on the cover of the 1964 American edition of her Selected Poems, but this one was written with the benefit of inside knowledge, as Smith provided the blurb herself.

There may be echoes in her work of past poets-Lear, Poe, Byron, the gothic romantics and Hymns Ancient and Modern-but these are deceitful echoes, as her thoughts may also seem deceitful, at first simple, almost childlike, then cutting at depth with a sharp edge to the main business of her life- -death, loneliness, God and the devil. ${ }^{14}$

Hermione Lee, whose own list also begins with Blake, makes the important point that "mixed with this strong attachment to the English tradition, there is a powerful feeling for Greek and French classical tragedy, for Virgil, Homer, Catullus, Plotinus and Seneca, for the liturgy and the Book of Common Prayer". ${ }^{15}$ Yet, despite his own powerful feeling for classical literature and the Book of Common Prayer, the author of The Waste Land is seldom mentioned in relation to Smith's work. Frances Spalding does suggest that "there are poems in which the influence of Eliot can be detected", but she goes on to say:

modernism was not her chosen inheritance. Instead her poetry ranges freely over associations connected with older traditions, forms and genres. [ ... ] Her aim was to write poetry that comes to the lips as naturally as speech. In this she is an inheritor of a tradition that looks back to the Lyrical Ballads and beyond. But her liking for simplicity, her refusal to overdecorate her themes, is only one aspect of her poetics. Another is her constant use of quotations, half-quotations, travesties, echoes and allusions drawn from the work of other poets whose voices infiltrate her own. ${ }^{16}$

Eliot's biographer Robert Crawford makes the point that Eliot's poetry too, "up until The Waste Land and beyond", is characterized by the use of "allusion, quotation, echo and resonance", and goes on to compare him to another writer with a distinctively idiosyncratic voice:

both these poets are tradition-bearers whose ideas blended continuity and disruption, fusing modern literary culture with oral heritage. Some of the most powerful lines in Eliot's work, after all, come from nursery rhymes-whether The Waste Land's "London Bridge is falling down falling down falling down" (a telling line in a poem obsessed with loss of connection), or that distorted nursery rhyme beginning "Here we go round the prickly pear" in "The Hollow Men". 17

The poet in question is Robert Burns, but the passage could just as easily be applied to Stevie Smith.

This is not to suggest that the major themes, which, in addition to "death by water", ${ }^{18}$ she shares with Eliot-Anglicanism and the modern reworking of classical literature, with a strong emphasis on female figures - were initially inspired by her reading of his work. Unsurprisingly, these similarities

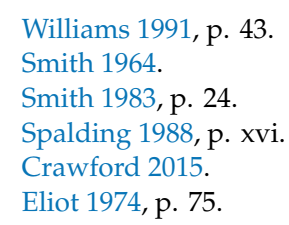


involve marked oppositions. Where Eliot manages to make even the fractured idioms of modernist poetry sound lapidary and authoritative, Smith shows a ventriloquist's skill in creating a range of speaking voices to portray or embody the characters in her poems. In contrast to Eliot's adult conversion to Anglo-Catholicism, Smith was an adult convert to agnosticism, engaging in a passionate poetic argument with the faith of her childhood; and, in one trenchant essay, in a passionate exposition of the case against Murder in the Cathedral, ${ }^{19}$ undeterred by the fact that this hatchet job was her contribution to a symposium for Eliot's seventieth birthday. Above all, where the female figures in The Waste Land are parodic and diminished contemporary versions of their classical originals, Smith enters her classical sources, reimagining them from within. Through her off-key subversion of the story material, too ancient and powerful to be subdued, which binds Phèdre, Antigone, Persephone and Helen of Troy to their fates, she creates a kind of narrative double vision, which, paradoxically, endorses the inevitability of the tragic dénouement. These themes, the classical but also the Christian, culminate in poems celebrating and ultimately invoking death as Thanatos, the only god who comes as a servant, and puts a merciful end to stories by "scattering ... the human pattern altogether". ${ }^{20}$

Although Virginia Woolf was impressed by Eliot's reading of The Waste Land, writing that "He sang it \& chanted it rhythmed it", ${ }^{21}$ surviving recordings no longer capture the excitement of that experience. However, as the actor Fiona Shaw has demonstrated, the poem comes vividly alive in performance, taking the listener into a space disturbingly full of multi-layered narrative echoes. The critic Daniel Albright, commenting on just one of these compound narratives, tells us that:

Throughout the text, the poet juxtaposes the designified present with the significant past; he reminds us, for example, that Philomel suffered her rape so intensively that she turned into a nightingale, sheer urgent expressive form; whereas the typist suffered her "rape" (or unwanted but unprotested sexual violation) so inertly, so complacently, that she turned into-nothing at all. ${ }^{22}$

While we might well take odds with that "complacently", more than one narrative is being robbed of its classical significance here. In A Game of Chess, Philomel, "so rudely forced" by Tereus, becomes a nightingale whose supposedly "inviolable voice" is immediately violated by the following two lines: "still she cried and still the world pursues,/'Jug Jug' to dirty ears." 23 The conventional onomatopoeic representation of the nightingale's song becomes a crude term for copulation, so that when we hear it again in The Fire Sermon, in a burst of birdsong ending with a "Tereu" which reminds us of Philomel's assailant, we already know what is about to happen to the typist, whose return home also parodies one of the most famous fragments of Sappho. In a mocking echo of the silencing of the raped Philomel, whose tongue is cut out by her attacker, Eliot also parodies the seduced Olivia's song from The Vicar of Wakefield, "When lovely woman stoops to folly", silencing that too. The nearest that the nameless typist can come to expressing her predicament through music is to put "a record on the gramophone". ${ }^{24}$

Even the female speakers in the poem-with the exceptions of the hyacinth girl, a would-be fertility figure whose lover is unable to respond to her, the sinister Madame Sosostris and poor Lil's garrulously treacherous friend-express only emptiness, apathy and despair: the medieval sin of accidie. "I read, much of the night, and go south in the winter." 25 "I can connect/Nothing with nothing." 26 "What shall we do tomorrow?/What shall we ever do?"27 Whether based on Shakespearian

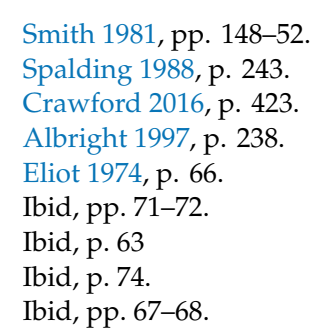


or Ovidian heroines, Spenserian nymphs, Wagnerian river daughters, or a Dantean soul in Purgatory, they are represented as the unpitiable victims of neurosis, "unwanted" (or, in the case of the now absent nymphs, remunerated) "sexual violation", marital breakdown and marital rape. The modern Waste Land is spiritually barren because it is a place where the ancient, shaping power of story has been destroyed.

By contrast, as Will May ${ }^{28}$ points out, "Smith's poems with explicit classical reference points" are "far from being travesties, parodies, or lampoons", and yet that "commonplace in feminist criticism", "the notion of the female poet as triumphal revisionist", does not apply to her in the way one might expect. Poems such as U.A. Fanthorpe's Not My Best Side, and collections such as Carol Ann Duffy's The World's Wife turn familiar stories inside out, making witty feminist polemic out of the ragged seams that appear to have been exposed, but in the process some of the power of the original story is lost, and it is precisely that power which Smith wants to harness. May rightly says that she "chooses tragic heroines at their point of crisis", but her "interpretations" do not simply "restate and protect notions of lineage and fidelity" to original texts, as he suggests, but seek to explore the exacting and implacable nature of tragedy itself, as she demonstrates in a 1965 interview on the BBC arts programme, Monitor.

Her unseen interviewer, the documentary-maker Patrick Garland, ${ }^{29}$ speaking of her exceptional memory for verse, mentions that as a girl "she learnt by heart one hundred and thirty-six lines of Greek phonetically" for "a school production of The Bacchae by Euripides". Smith quotes a snatch of the still-remembered speech, then gives a brilliantly condensed, extempore account of the ending of the play, punctuated by laughter at the sheer horror of what she is describing:

'the mother coming on, Agave coming on, thinking it's the head of a young lion and stroking it. It's really the head of her son. And Tiresias says, 'You know, I don't think you know what you have in your arms. It's not a young lion at all, it's the head of your son which you've torn off. [ ... ] Then when this wretched Dionysus comes on at the end and says, 'It will cure you of this terrible sin of impiety towards the gods won't it, anyway'. And the queen, Agave, says, 'But is there no mercy? Must we now be sent into exile? Is there no help?' And then she looks at him and she says, 'I see there is no help,' and he said, 'Why then postpone the necessity? Why then postpone the inevitable?' Turns on his heel and leaves. Everything in ruins, you see. ${ }^{\prime 30}$

When Garland, in the subdued voice of a man who has been unexpectedly purged by pity and terror on national television, replies, "I suppose there is no help, really," she tells him tartly that "we create our own gods", so shouldn't "create gods of such atrocity, really, as these Greek gods", adding, "Oh it's an extraordinary religion. I don't know whether they believed it."

The cruelty of the Greek gods is central to Smith's poem Phèdre, ${ }^{31}$ which superficially appears to be an example of the female poet as "triumphal revisionist", wrenching an improbable happy ending out of the resistant matrix of Racine's tragedy. However, the narrative voice, which becomes ever more disingenuous as the poem nears its mock-hopeful conclusion, is not that of Smith herself. In Novel on Yellow Paper, she tells us that Racine's Phèdre rather than Euripides Hippolytus seems to her to be "truly Greek", ${ }^{32}$ because "the plot of a tragedy must be bone-straight and simple". ${ }^{33}$ Both plays tell "the same story ... but Euripides is very profoundly restless, so it disturbs the tragedy", ${ }^{34}$ while in Racine's Phèdre, "the verse and the emotion are perfectly at one, they fuse perfectly and effect the purgation

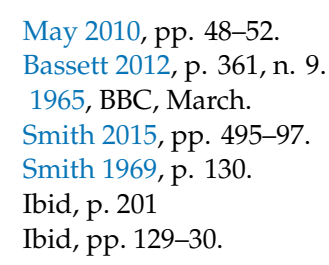


which is the essence of tragedy". ${ }^{35}$ In conversation with Kay Dick in the last year of her life, Smith tells her, "It's a play that means a lot to me. A play I would go to when I've been depressed and terribly sad." 36

In the poem, the classical Phèdre's shame is made worse by nowadays being played, "with awful ancient agonizing", by mature actresses "like Marie Bell". When that celebrated French diva was filmed in the role in her late sixties, the New York Times critic Vincent Canby commented diplomatically, "At this point, Miss Bell is somewhat too majestic to be entirely convincing, even at the center of a tragedy of intellect, but she is a living landmark not easily denied". ${ }^{37}$ The Phèdre of Smith's poem is young, "A girl caught in a trap", and the speaker tries to rescue her by rewriting the play as a comedy. This attempt, which absurdly hinges on warding off "Vénus toute entière à sa proie attachée" 38 with a half-pound box of soft-centred chocolates, is followed by a return to the dark family history which makes the opening lines from Racine:

Depuis que sur ses bords le dieux ont envoyé

\section{La fille de Minos et de Pasiphaé 39}

"As lucid as they are alarming". The end of the poem plays with the key word "simple", which Smith uses in Novel on Yellow Paper to characterize the essential nature of tragedy. The optimism of the retelling almost founders on the question of whether "poor simple honourable sweet prim Phèdre" can really be simple enough "To be happy with a prig like Hippolytus". The speaker rallies gamely:

I think it could have been a go,

If I were writing the story

I should have made it a go.

But, as the conditional tense reminds us, and the opening lines from Racine have already made plain, it is the gods who are writing this story, one in which Venus, "Ancient enemy/Of her family", has already doomed Phèdre before she even sets eyes on Hippolytus.

Smith's sketchbook, Some Are More Human Than Others, includes a drawing of a grimly scowling girl with the caption, "I am Antigone and I shall bury my brother!" 40 However, Smith chose a different illustration for Oh stubborn race of Cadmus' seed ..., ${ }^{41}$ one so integral to the poem that she included a description of it in the introduction, almost a poem in itself, with which she prefaced it in performance:

From Hades, with the fire-flush of Hell upon her cheeks, comes the young Antigone, with a backward-looking, repentant thought for the sister she used to despise so much, the soft

Ismene. Antigone is a very young girl, she stands with bows in her hair, and on her outstretched arm she supports a large and melancholy bird. ${ }^{42}$

The critic Laura Severin takes Smith's insistence on Antigone's youth to mean that she is "a naïve innocent", "caught in a world whose rules are not of her making", whose "rebellion ends merely in her own death". ${ }^{43}$ But in fact, it is only in the introduction, not in the poem itself as Severin suggests, that Antigone "walks in the Dark Hall of Hades". The poem, as Smith emphasized in performance by

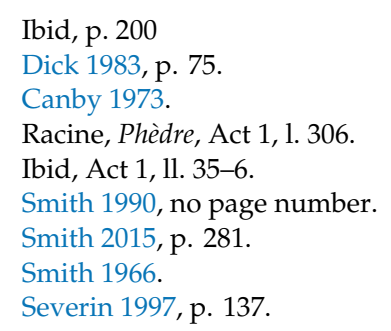


chanting it in her "beautifully flawed plainsong", is a funeral ritual which enacts what it describes. The bird Antigone is holding is "the bird of burial" which she invokes as she throws the dust which symbolically buries her brother and metaphorically blinds her uncle Creon. It will only be after they have killed her, as she knows they must, that she will "stand in the dark hall", pitting the human capacity for forgiveness against the hostility of the gods to the house of Cadmus by crying "Orchus, see that my sister does not suffer at all."

While Smith's Antigone proudly determines her own fate, as she does in Sophocles' tragedy, she will come to understand, in the dark hall of Hades, that the bond of kinship extends beyond her dead brother to the cowardly but loving sister whose wish to die with her she had contemptuously refused. For Smith's Persephone, "the halls of Hades" are a place of escape from the smothering bond of maternal love. Unlike Milton's kidnapped girl, who

gathering flowers

Herself, a fairer flower, by gloomy Dis

Was gathered, ${ }^{44}$

she deliberately chooses the icy underground world and summons its dark King:

Oh can you wonder can you wonder

I struck the doll-faced day asunder

Stretched out and plucked the flower of winter thunder ${ }^{45}$

In a radio broadcast for schools, Smith told her young listeners:

The story of Persephone is a story of Winter and Summer, but in my story I have made Persephone a girl who loves winter, and snow, and the curious light you get when there is snow on the ground and you look up, if you are in the house, and the ceilings are bright with the reflection of snow. In my poem, Persephone even likes the dark places in her kingdom, which can be frightening [ ... ] There is another thread in this poem-it is what she feels about her mother. She loves her, but at the same time she does not want to be sought for all the time, and wept for, and begged to come home. She wants to be herself, and free to stretch out and take her time. ${ }^{46}$

This is just one of the narrative threads which link Smith's Persephone to the speaker in I rode with my darling ... who defies the repeated warning, "do not stay alone in the dark wood at night", and chooses to be lost.

Loved I once my darling? I love him not now.

Had I a mother beloved? She lies far away.

My sister, a loving heart? My aunt a noble lady?

All all is silent in the dark wood at night. ${ }^{47}$

The autobiographical details suggest that the unnamed protagonist is Smith herself, but this is autobiography in reverse, an imagined escape from the sometimes painful bonds of family love which held her all her life. In Novel on Yellow Paper, she describes the trauma of her mother's death from heart disease and her own anguish at being unable to help her:

\footnotetext{
44 Milton, Paradise Lost Bk IV, 11. 268-72.

45 Smith 2015, p. 283.

46 Barbera and McBrien 1986, p. 167.

47 Smith 2015, p. 297.
} 
about this time when it was cold and dark and damp and February my darling mama died.

What can you do? You can do nothing but be there and go on being there steadily and without a break until the end. There is nothing but that that you can do. ${ }^{48}$

Although the Persephone of the poem responds to her mother's bitter and sorrowful calling of her name with a cry of "No returning" as she experiments with the wintery pleasures of her new kingdom, "Snow-drifts on the fingers burning", she is in denial about the cyclical nature of her own story. As Smith points out in the radio talk, "She might not like it so much if she had to stay there all the time".

I had a dream $\ldots{ }^{49}$ is the poem which comes closest to Eliot's treatment of female figures in The Waste Land, but here the contemporary version of a classical protagonist finds herself inside the original story. Inevitably, in performance, the opening lines of the poem:

I had a dream I was Helen of Troy

In looks, age and circumstance,

But otherwise I was myself,

identifies the speaker with Smith, but the comic impact of this is short-lived. The dream-Helen, who remembers "Everything one has ever read about Troy", quotes from Lorenzo's speech in The Merchant of Venice:

In such a night as this,

When the sweet wind did gently kiss the trees,

And they did make no noise, in such a night

Troilus methinks mounted the Trojan walls,

And sigh'd his soul toward the Grecian tents

Where Cressid lay that night. ${ }^{50}$

and tests it against the brutal reality of war:

Where Cressid lay that night, except they did not say

How beastly Scamander looks under this sort of sky,

And the black Greek ships piled up on the seashore beyond

Like prison hulks, like slugs.

Smith's poem, like Eliot's, is haunted by World War One, but where he uses the imagery of the trenches to explore a toxic personal relationship: "I think we are in rats' alley/Where the dead men lost their bones", 51 she draws on the childhood memories she recounts in A Soldier Dear to Us, in which reading Browning's Childe Roland to the Dark Tower Came at school enables her to visualize the nightmare landscape of the Somme:

Basil never spoke of the trenches, but I

Saw them always, saw the mud, heard the guns, saw the duckboards,

Saw the men and the horses slipping in the great mud ... ${ }^{52}$

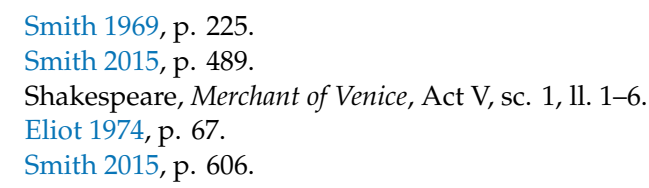


The dream-Helen has entered the story at an "ominous eternal moment": eternal both because of the psychological trick which makes time seem to stop for those awaiting imminent disaster and because this moment of pause must recur in every retelling of the fall of Troy. The dream-Helen, although, like a second Cassandra, she knows what must happen, is powerless either to avert or to explain the coming catastrophe to the other characters, whose fear of the gods helps to trap them in the unchangeable epic narrative. All she can do, "when the pause finishes", is to wake.

"Very cruel, very callous, we think the Olympians", Smith tells us in Novel on Yellow Paper, "but of course it is hardly their fault. They have no heart. They have no heart." 53 She was far more troubled by the cruelty of the Christian God, though she struggled to separate herself from the beliefs and rituals of her Anglican childhood. In her third novel, The Holiday, which reflects the pain and conflict of that struggle, Celia accompanies her clergyman uncle Heber into his empty country church:

It is the twenty-eighth evening of the month. I hear my gentle uncle saying softly the psalms for the evening: 'Blessed shall he be that taketh thy children; and throwest them against the stones. ${ }^{.54}$

Smith quotes this psalm again in "The Necessity of Not Believing", her lecture "to the Cambridge Humanists on an anti-religious subject", in which she speaks of "the terrible pictures" Goya "made in the prisons of the inquisition", evidence of a human cruelty which it is impossible for "the Christian of today" to "separate himself from" and "utterly condemn".

For their gentle Christ was more cruel than this, for the worst cruelties of men end with death, and hell is eternal, and Christ made himself the King of Hell and the judge of torments. For he said that the Son of Man should come in glory and judge both the quick and the dead, and that he should say to the sinning people: Depart from me, ye cursèd, into the everlasting fire ... where their worm dieth not and the fire is not quenched. ${ }^{55}$

Smith's acceptance of "the emptiness of an indifferent universe", 56 in preference to the superficial sweetness of a religion which she saw as implacably wedded to "the doctrine of eternal pain", ${ }^{57}$ informs her 1958 essay on Murder in the Cathedral, in which she describes Eliot's play as "a remarkable evocation of Christian fears, remarkable for the strength of these fears and the horrible beauty in which they are dressed". ${ }^{58}$ Although she admitted that her essay was "a very un-birthday present" 59 to the seventy-year-old poet, she cannot be said to have misrepresented Eliot's belief in the spiritual need for religious dread. In a letter of 1930, he tells the Christian apologist Paul Elmer More that to him, Hell is "giustizia, sapienza, amore", [justice, wisdom, love], words taken from the dark inscription above Hell Gate in Dante's Inferno:

Giustizia mosse il mio alto fattore;

fecemi la divina podestate,

la somma sapienza él primo amore.

[Justice moved my high maker;

I was made by divine power,

supreme wisdom and primal love.]

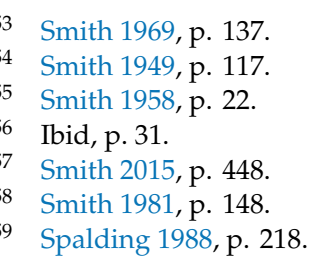


The inscription famously ends in the line, "Lasciate ogne speranza, voi ch'intrate." [Abandon all hope, you who enter] ${ }^{60}$ Eliot sees More's failure to share this belief as a lapse into Humanism, asking him, "Is your God Santa Claus?", and goes on to say:

To me, religion has brought at least the perception of something above morals, and therefore extremely terrifying. It has brought me not happiness, but the sense of something above happiness and therefore more terrifying than ordinary pain and misery; the very dark night and the desert. To me, the phrase 'to be damned for the glory of God' is sense not paradox; I had far rather walk, as I do, in daily terror of eternity, than feel that this was only a children's game in which all the contestants would get equally worthless prizes in the end. ${ }^{61}$

By contrast, in "The Necessity of Not Believing", Smith yet again enters an ancient and powerful narrative, reimagining the story of the crucifixion from the inside, not simply for polemical purposes but with a real and pitying sense that if the historical Christ was human and not divine, this is how he might have suffered on the cross.

I have thought that as his life of teaching passed, so his exigencies grew, and his claims grew greater-that he was now divine-and people would not listen to him, and in the end he threw himself upon the cross as the Victim and Sufferer Isaiah spoke of [ ... ] And then comes that terrible cry from the cross, 'My God, my God, why hast thou forsaken me?' Was it then, that not the mercilessness of men, not the cruelty of the Law, touched him, but the indifference of Nature and the universe, an empty sky, the coming of Death as a friend, as Man's only true friend. Come quickly then, Death, one must have prayed at that moment as for all poor men at the point of anguish. ${ }^{62}$

Christian composers have traditionally incorporated that cry of Eli, Eli, lama sabachthani into passion music or oratorios on the Seven Last Words from the Cross, making it a support rather than an impediment to faith, but here, comfort is to be found elsewhere, in the idea that even for the suffering Christ "quiet Death" offers "end and remedy". In her poem My heart goes out ... , Smith speaks of her love for her Creator, who has given her, and "all living creatures", that ultimate solace, "which is what they want although/When they are living they do not think so." ${ }^{\prime 63}$

But although she continued to question and argue with the faith she had renounced in poems such as Oh Christianity, Christianity, ${ }^{64}$ Smith also reimagines the figure of Christ in a very different way in one of the most beautiful religious poems of the twentieth century, though one that Eliot would have seen as heretical for its denial of "the dark night and the desert", which were central to his own Dantean belief system. The Airy Christ, written after reading E.V. Rieu's translation of St Mark's Gospel, offers us a Christ who "comes in grandeur" not as a judge of the quick and the dead but as a "sweet singer" who "aloofly" foresees that his hands and feet must be nailed to the "wooden bands" of the cross, yet "does not care that he was crucified":

For he does not wish that men should love him more than anything

Because he died; he only wishes they would hear him sing. ${ }^{65}$

In her interview with Kay Dick, Smith told her, "I'm supposed to be an agnostic, but I'm sort of a backslider as a believer, too. I mean I'm a backslider as a non-believer, because every now and then I think, 'No, I have this feeling that ... '"'66

\footnotetext{
Dante, Inferno, Canto 3, 11 4-9.

Eliot 2014, pp. 209-10.

Smith 1958, pp. 31-32.

Smith 2015, p. 422.

Smith 2015, p. 484.

Smith 2015, p. 396.

Dick 1983, p. 71.
} 
Yet, as she points out in Novel on Yellow Paper, there is an important sense in which Smith had already ceased to be a Christian while she was still a small child, despite being "brought up in an extremely religious way, in a household where there was great love, and a great faith in the Christian religion according to the tenets of the Church of England." ${ }^{\prime 67}$ She spent three years from the age of five in a convalescent home suffering from tubercular peritonitis, and it was there that she first found strength and comfort in the thought of death by suicide.

To brace and fortify the child who already is turning with fear and repugnance from the life he is born into, it is necessary to say: Things may easily become more than I choose to bear. That is a very healthy and a very positive attitude. But you should point out that the child is at once no longer a Christian. For the thought: Things may easily become more than I can bear, leaves him a Christian, if a half hearted, faithless sort of a Christian [ ... ] But that 'choose' is a grand old burn-your-boats phrase, ${ }^{68}$

and one which requires a return, even if only a metaphorical one, to the beliefs and values of the classical world.

So teach your little ones to look on Death as Thanatos-Hades the great Lord of the Dead, that must, great prince though he be, come to their calling. And on the shadowy wings of this dark prince let them be borne upwards from the mire of makeshift and fearful compromise. ${ }^{69}$

In her essay "Too Tired for Words", Smith describes "putting something into the last two lines" of her version of Dido's Farewell to Aeneas "that is not quite in Virgil, to express this proud thought of commanding the great god Thanatos":

'Come Death, you know you must come when you're called

Although you're a god. And this way, and this way, I call you. ${ }^{70}$

In the original passage from Book IV of The Aeneid, Dido stabs herself to death in the hope that the sight of her funeral pyre will bring ill fortune to her faithless lover as he sails away from Carthage:

$$
\text { "moriemur inultae, }
$$

sed moriamur," ait. "sic, sic iuvat ire sub umbras.

hauriat hunc oculis ignem crudelis ab alto

Dardanus et nostrae secum ferat omina mortis."

"I shall die unavenged," she cries, "but let me die! Thus, thus I go gladly into the dark! Let the cruel Dardan's eyes drink in this fire from the deep, and carry with him the omen of my death!"71

Smith's version turns this into an active, rather than a despairing, summoning of death. Her Dido relegates Aeneas to the past, though admitting she might have been happier had they never met; despite dying unavenged, she cries, "I die as I choose". Smith takes the gladness of "sic, sic iuvat ire sub umbras" literally, and uses the scansion of the final line to translate the first two words of the phrase into two thrusts of the dagger: "This way, and this way I call you." Later in the essay, she complains that "Christianity absolutely will not allow us this delicious idea of command over Death,

\footnotetext{
67 Smith 1958, p. 19.

68 Smith 1969, p. 160.

69 Ibid, p. 161.

70 Smith 1981, p. 112

71 Virgil 1932, Bk IV, 1l. 659-62.
} 
preferring to team up on this point with Old Mother Nature, that bloody-minded Stakhanovite with her brassy slogan 'Production at all costs."72

Smith's suggestion in Novel on Yellow Paper that "every intelligent, sensitive child should early be accustomed to the idea of death by suicide" 73 may seem deliberately provocative, but in fact she was perfectly serious about it. In the preface to her anthology for children (a mind-stretching collection including extracts from The Book of Job, Chaucer in the original, and Shelley's The Masque of Anarchy), she tells her young readers:

Childhood's thoughts can cut deep. I remember when I was about eight, for instance, thinking the road ahead might be rather too long, and being cheered by the thought, at that moment first occurring to me, that life lay in our hands. Many poems have been inspired by this thought, at least many of mine have been. ${ }^{74}$

She continued to find strength and comfort throughout her adult life in the idea that death must come if she called him.

It is important to stress, though, that this does not mean that she was suicidal in the Sylvia Plath sense, despite the painful incident in 1953 when she cut one of her wrists in the office. Probably more an act of self-harm than a serious attempt at summoning Thanatos, this was completely successful as a cry for help (unlike the fruitless efforts of the drowning man in her most anthologized poem), releasing her with a pension from the dull misery of the secretarial job she had come to hate. Though remorseful at having caused distress to her aunt, she wrote cheerfully to a friend, "I have been pensioned off and am so glad. The doctor said "No more" heaven bless him. So now I do nothing but write poems." 75

However, despite this incident, Smith's considered take on the subject of suicide is that having the choice to die is an aid to living with fortitude since that too becomes a matter of choice. In the poem Exeat, she recalls the story of the Roman emperor who used to tell his "poor prisoners cramped in dungeons" that "they were not yet friends enough for him to give them death", and asks sternly,

How can a poet commit suicide

When he is still not listening properly to his Muse,

Or a lover of Virtue when

He is always putting her off until tomorrow? ${ }^{76}$

However, the end of the poem, in which Life finally comes with love to the weary and enfeebled old person, giving him permission to die, led to some rather alarming correspondence:

I keep getting letters from people asking if I will join them in a suicide club. And one lady asked me to tell her how to "manage it" as she couldn't swallow pills. I always write back the most bracing letters telling them to hang on as long as possible as it's absolutely nothing compared with geological time. And that I am afraid it is something they must decide for themselves, I did not say, Get your doctor to prescribe it in liquid form! ${ }^{77}$

Although her suicide attempt of 1953 seems to have been triggered by clinical depression, Smith did not habitually couple death with despair as critics often suppose. Interviewed by John Gale of The Observer in 1969 as the winner of the Queen's Gold Medal for Poetry, she copied out "in a good hand a poem about death, which, she thinks, may 'cheer up her Majesty' [ ... ] The first line of this poem is

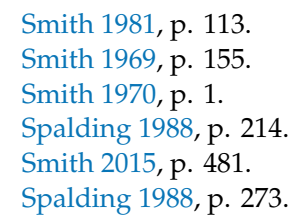


'My heart goes out to my creator in love.'" Although the irony of offering a poem in praise of "quiet Death" to a monarch whose subjects sang "Long live our gracious Queen" on every public occasion cannot have been lost on Smith, the gift was in its way sincere, though doubtless never delivered. She tells Gale:

I do really think death will be absolutely marvellous. I don't think one could possibly enjoy life without death; one couldn't stand it; not only the pain, but the pleasure. If there wasn't death, I think you couldn't go on.

It's like being drawn into a race of water before it gets to the waterfall. It gets quicker and quicker and more exciting. The older you get the more exciting it gets. I don't know why people have been taught to be afraid of death. If a human being was left to itself I don't think it would fear death. We're taught to believe death is the greatest calamity. It's the greatest blessing. ${ }^{78}$

To the frustration of her biographers, Smith was a writer who managed to keep the details of her private life almost entirely private. Apart from Margaret Spear, the indomitable Lion Aunt, whose steadfast and loving companionship was the bedrock of her life, the most intimate relationship Smith ever writes about is her relationship with death, which she explores in poems ranging from Tender Only to One, the title poem of her second collection in 1938, to Black March in her posthumously published final volume, Scorpion and Other Poems. "I love death", she told Kay Dick, "I think it's the most exciting thing," ${ }^{\prime 79}$ while her retort to the composer Elizabeth Lutyens: "When you say 'won't death be a bit of an anti-climax when you come face to face?' you sound rather as if you had met him and found him not quite the dish I thought" ${ }^{\prime \prime}{ }^{80}$ is almost that of a jealous lover.

In one of the most serene and joyful of these poems, Venus When Young Choosing Death, Smith invents her own classical myth about death by water. The Venus of the poem is young, as Phèdre and Antigone are young, the age at which the heroine of an archetypal story chooses her fate or is chosen by it. Standing knee-deep in the warm sea from which she was born, she embraces her fellow gods, who kiss her one by one "in friendship" and bid her farewell. The boatman she is waiting for is no Charon, but a tenderly erotic figure who wears and holds the poppies she tastes on his lips as he kisses her:

Sleep or Death, Sleep or Death kissed me,

Not for friendship.

You do not kiss one for friendship?

No, for welcome,

To welcome one home. ${ }^{81}$

In her final book of poems, Smith returns to this self-created myth in Oblivion. Once again, the speaker is standing "in a sweet and milky sea, knee deep," and "growing deeper", but this time she is called back, despite her reluctance, by "a human and related voice/That cried to me in pain." It is impossible not to hear that human voice as the voice of the Lion Aunt, frail and in her nineties and soon to die herself, calling her beloved Peggy back from the seductive mists of "sweet oblivion". But the speaker in this poem, unlike Venus, is mortal, so she can afford to wait:

those sweet seas that deepen are my destiny

And must come even if not soon. ${ }^{82}$

78 Gale 1969.

79 Dick 1983, p. 71.

80 Smith 1981, p. 321.

81 Smith 2015, p. 527. There is a misprint in this poem in May's edition: the line beginning 'Then came out ... ' should read 'Then came one...'

82 Ibid, p. 646. 
In the event, she did not have to wait for long. Stevie Smith wrote her last poem, Come Death (2), while undergoing medical tests for the symptoms, including aphasia, of an incurable brain tumour. In eight short lines, she makes the choice to turn for help not to the Christian God but to the only god who comes as a servant, summoning him at last in words which brook no denial:

Listen then to this sound I make, it is sharp,

Come Death. Do not be slow. ${ }^{83}$

The closing lines echo the speech she gave to Dido, but with the sharpness of a cry rather than a blade. When a friend visited her in hospital, bringing a typed copy of the poem:

although her speech had not been good for some time (she had been missing words), Stevie read the poem aloud perfectly. It was a dramatic moment. Visitors, who were on their way out, stopped. ${ }^{\prime 84}$

In "Stevie: A Personal Memoir", her friend and executor James MacGibbon describes how, with "her speech incoherent but her mind unimpaired", she showed him the typescript of the poem, on which she had "made a ring round the word 'death' indicating that she wanted to die without delay", after which an understanding doctor "sedated her more and more heavily" as she slipped quietly away from life.

There was no more conversation on subsequent visits and all we could do was to hold her hand and hope she realised we loved her. On 7 March 1971 she died, peacefully as far as we could tell. I read that last poem at her funeral. She had written her own oration. ${ }^{85}$

Stevie Smith is still too often thought of as a writer of light verse, though her subject matter could be as dark and weighty as that of T.S. Eliot, a writer she was not afraid to cross swords with. Her greatness as a poet lies in the way she uses her distinctive voice to illuminate the darkness of her material with flashes of startling insight and leaven its heaviness with laughter. Both a ventriloquist and a truth-teller, her work reshapes the limits of what literature can tell us about life and, especially, death as radically as that of any modernist poet.

Funding: This research received no external funding.

Acknowledgments: I am grateful to Jane Dowson and Mary Sue Daoud for their editorial support and encouragement; to Noreen Masud and Frances White, the organisers of "We All Have These Thoughts Sometimes": A Conference on the Work of Stevie Smith, Jesus College Oxford 11 March 2016; and to Stevie Smith herself.

Conflicts of Interest: The author declares no conflict of interest.

\section{References}

Albright, Daniel. 1997. Quantum Poetics: Yeats, Pound, Eliot and the Science of Modernism. Cambridge: Cambridge University Press.

Barbera, Jack, and William McBrien. 1986. Stevie: A Biography of Stevie Smith. London: Macmillan Papermac.

Bassett, Kate. 2012. In Two Minds: A Biography of Jonathan Miller. London: Oberon Books.

Bedient, Calvin. 1991. Horace and Modernism. In In Search of Stevie Smith. Edited by Sanford Sternlicht. New York: Syracuse University Press, pp. 166-68.

Canby, Vincent. 1973. 'The Screen: Phèdre Is a Graceful Homage to Racine'. The New York Times. March 30. Available online: https://www.nytimes.com\T1 \textgreater\{\}archives (accessed on 25 August 2019).

Crawford, Robert. 2015. TS Eliot: The Poet Who Conquered the World, Fifty Years on. The Guardian. January 10. Available online: https://www.theguardian.com\T1\textgreater\{\}jan (accessed on 8 August 2019).

83 Ibid, p. 658.

84 Barbera and McBrien 1986, p. 292.

85 Smith 1990, p. 14. 
Crawford, Robert. 2016. Young Eliot: From St Louis to the Waste Land. London: Vintage.

Dick, Kay. 1983. Ivy \& Stevie: Ivy Compton-Burnett and Stevie Smith. London: Allison \& Busby.

Eliot, Thomas Stearns. 1974. Collected Poems 1909-1962. London: Faber \& Faber.

Eliot, Thomas Stearns. 2014. The Letters of T.S. Eliot, Volume 5, 1930-1931. Edited by Valerie Eliot and John Haffenden. New Haven: Yale University Press.

Gale, John. 1969. Death is a Poem to Stevie Smith. The Observer, November 9.

Heaney, Seamus. 1991. A Memorable Voice: Stevie Smith. In In Search of Stevie Smith. Edited by Sanford Sternlicht. New York: Syracuse University Press, pp. 211-13.

Jenkins, Amy. 1915. Waving or Drowning? Amy Jenkins on Her Debt to Stevie Smith. The Guardian. April 4. Available online: https://www.theguardian.com\T1\textgreater\{\}apr (accessed on 13 April 2019).

May, William. 2010. Stevie Smith and Authorship. Oxford: Oxford University Press.

Monitor. 1965. BBC London, March, stevie smith monitor bbc archive. Available online: https://www.bbc.co.uk/ T1\textgreater\{\}zkrwcqt (accessed on 10 August 2019).

Nash, Ogden. 1964. Promotional Card for Stevie Smith. In Selected Poems. New York: New Directions.

Orr, David. 2016. Freely Rhymed: 'All the Poems of Stevie Smith'. The New York Times. April 22. Available online: https://www.nytimes.com\T1\textgreater\{\}review (accessed on 27 August 2019).

Severin, Laura. 1997. Stevie Smith's Resistant Antics. Madison WIS: University of Wisconsin Press.

Smith, Stevie. 1949. The Holiday. London: Chapman \& Hall.

Smith, Stevie. 1958. The Necessity of Not Believing. Gemini 2: 19-32.

Smith, Stevie. 1964. Selected Poems. New York: New Directions.

Smith, Stevie. 1966. Stevie Smith reads Selected Poems. The Poet's Voice Series; Hessle: The Marvell Press.

Smith, Stevie. 1969. Novel on Yellow Paper: Or Work It out for Yourself. London: Jonathan Cape.

Smith, Stevie. 1970. The Batsford Book of Children's Verse. Edited by Stevie Smith. London: B.T. Batsford.

Smith, Stevie. 1981. Me Again: The Uncollected Writings of Stevie Smith. Edited by Jack Barbera and William McBrien. London: Virago.

Smith, Stevie. 1983. Stevie Smith: A Selection. Edited by Hermione Lee. London: Faber \& Faber.

Smith, Stevie. 1990. Some are More Human than Others: A Sketchbook. London: Peter Owen.

Smith, Stevie. 2015. The Collected Poems \& Drawings of Stevie Smith. Edited by Will May. London: Faber \& Faber. Spalding, Frances. 1988. Stevie Smith: A Biography. New York and London: W.W. Norton.

Virgil. 1932. The Aeneid. Translated by H. Rushton Fairclough. The Loeb Classical Library. Cambridge: Harvard University Press.

Williams, Jonathan. 1991. Much Further Out Than You Thought. In In Search of Stevie Smith. Edited by Sanford Sternlicht. New York: Syracuse University Press, pp. 38-49. 